\title{
Chrome Liquor Recycling in Pigskin Tanning
}

\author{
Tomoyoshi KuBo and Yasuhiro IsHII \\ Tokyo Noko University, Faculty of Agriculture, Scleroprotein \\ and Leather Research Institute, Fuchu-shi 183
}

(Received October 23, 1980)

\begin{abstract}
Using technical experience in chrome liquor recycling for cattle-hide leather manufacture, applicability of the recycling system to pigskin tanning was investigated. When pigskins were tanned with sulfite-reduced chrome agent, the general composition and chrome complexes in spent chrome liquor recycled indicated no significant variations during sequential 11 runs of tanning. Moreover, the recycling of spent chrome liquor did not affect the chemical composition, mechanical strengths, and stiffness of resultant leather processed as the soft type pigskin leather. It was concluded that the chrome liquor recycling in pigskin tanning as well as in cattle-hide tanning could be recommended to put in practice.

Jpn. J. Zootech. Sci., $52(4): 308-313,1981$
\end{abstract}

Although pigskin are abundantly produced in Japan, only a limited number of research on the techniques for developing its leather-making potentiality has been reported. The authors have suggested some technical improvements for beamhouse operation in the previous papers ${ }^{1-9)}$ in a series of studies on pigskin leather-manufacturing techniques.

In the field of cattle-hide leather manufacture, the recycling of spent chrome liquor is recommended for reducing tannery effuent pollution and saving the chrome resources $^{4)}$. Davis and Scroggie ${ }^{5-8)}$, Burns et al. ${ }^{9)}$, France ${ }^{10)}$, Pierce and Thorsten$\mathrm{SEN}^{11)}$, BARLOW and $\mathrm{IP}^{12)}$, and NIWA et al. ${ }^{13)}$ already reported that the recycling did not affect the salt composition of spent chrome liquor and mechanical strength and quality of resultant leather substantially. The authors ${ }^{14)}$ also have reported that there is essentially no difficulty in the chrome liquor recycling from the study on its chrome complex composition.

When chrome tanning of pigskin is carried out, it may be less protected against relatively minor changes in the chrome liquor composition during recycling, because the structure of pigskin collagen is less stabilized compared with cattle-hide collagen ${ }^{15}$. Therefore, the effectiveness of chrome liquor recycling in pigskin tanning should be ascertained by more sensitive examinations of the mechanical property of leather. In the viewpoint described, the properties of pigskin leather produced from recycled chrome liquor were investigated in the present experiment.

\section{Materials and Methods}

Chrome tanning and the recycling of spent chrome liquor

After wet salted pigskins $(4.1 \mathrm{~kg} /$ piece) were soaked, limed, bated, and pickled 
Table 1. Procedures of chrome tanning

\begin{tabular}{ll}
\hline Material & : wet salted pigskin (4.1 kg/piece) \\
Wash & $:$ with $300 \%$ water for 20 minutes and with running water for 30 minutes \\
Soak & $:$ with $300 \%$ water and $0.8 \%$ sodium bicarbonate overnight \\
Lime & $:$ with $300 \%$ water, $3 \%$ sodium hydrosulfide, $0.8 \%$ sodium sulfide, $5 \%$ cal- \\
& cium hydroxide, and $0.3 \%$ nonionic surfactant overnight and split \\
Relime & $:$ with $400 \%$ water, $4 \%$ calcium hydroxide, $0.2 \%$ nonionic surfactant for 48 \\
& hours with intermediate scudding and weigh $\%$ on salted weight basis) \\
Delime/bate : & with $300 \%$ water $\left(33^{\circ} \mathrm{C}\right)$ and $2 \%$ ammonium chloride for 30 minutes, add \\
& $0.08 \%$ bating agent and $0.92 \%$ ammonium chloride, then run for 2 hours, \\
& pH 8.65 \\
Pickle & with $80 \%$ water, $8 \%$ sodium chloride, $1.5 \%$ sulfuric acid diluted with \\
& $10 \%$ water overnight, pH 2.85 \\
Tanning & with $30 \% \cdot$ water, $3 \%$ sodium chloride, and $8 \%$ chrome agent* for 30 min- \\
& utes and $0.88 \%$ sodium bicarbinate, then run for 60 minutes at $30^{\circ} \mathrm{C}$, add \\
& $60 \%$ water and run for 2 hours at $35^{\circ} \mathrm{C}$ and for 60 minutes at $40^{\circ} \mathrm{C}$, final \\
& pH 3
\end{tabular}

* Neochrome A from Nippon Denko Corp. (sulfite-reduced chrome agent)

under the condition given in Table $1,10 \mathrm{~kg}$ portion of pickled stock (equivalent to $15 \mathrm{~kg}$ in the limed weight) was subjected to chrome tanning as shown in Table 1. The spent chrome liquor was recovered and used for the base of tanning float of the subsequent tanning run. Thus, for the second and the subsequent runs, float of $90 \%$ water, $3 \%$ sodium chloride, and $10 \%$ chrome agent was replaced by that of $10 \%$ water and $80 \%$ spent liquor from the preceding run with supplemental addition of chrome agent to maintain the same chrome concentration. The tanning condition was same as that in the first run of tanning.

\section{Analyses of spent chrome liquor}

Spent chrome liquors were subjected to the following analyses after passing through 60-mesh screen and filterpaper of analytical grade.

COD (bichromate method) and $\mathrm{pH}$ were determined according to SMEWW method ${ }^{16)}$, chrome content and basicity according to ALCA method. Contents of sodium ion and chloride ion were determined by using specific ion-sensitive electrodes from Orion Corp., sodium ion electrode 94-11 and chloride ion electrode 94-17, respectively. Content of sulfate ion was determined by benzidine method and content of coordinate sulfate was calculated from the difference between contents of ionic and total sulfate determined gravimetrically after boiling the chrome liquor in $10 \%$ acetic acid solution for 60 minutes.

Charge distribution of chrome complexes in the liquor was characterized by fractionation on cation exchanging column, Dowex-50W-X 1, 100-mesh, Na-form; fraction 1 had no affinity to the resin, fraction 2 eluted with $0.1 \mathrm{~N} \mathrm{HCl}$ from the column and tentatively classified as [Cr] $]^{+}$complex, fraction 3 eluted with $3 \mathrm{~N} \mathrm{HCl}$ and classified as $[\mathrm{Cr}]^{+++}$complex, and fraction 4 eluted with $6 \mathrm{~N} \mathrm{HCl}$ and was classified as highly olated complex ${ }^{17)}$. Relative proportion of these fractions was calculated on the basis of chrome content. 
KuBo and IsHrl

Table 2. Neutralization, retanning, and fatliquoring of shaved stock $(1 \mathrm{~mm}$ thickness)

\begin{tabular}{ll}
\hline Wash & : with running water at $40^{\circ} \mathrm{C}$ for 10 minutes \\
Neutralize/retan: with $200 \%$ water at $40^{\circ} \mathrm{C}, 0.2 \%$ acetic acid, $1.5 \%$ glutaraldehyde \\
& agent 1 diluted with $3 \%$ water, $4 \%$ chrome agent for 90 minutes at \\
& pH 3.5 , add $1 \%$ Neutrigan diluted with $10 \%$ water, run for 30 minutes \\
& at pH 4 \\
Wash & $:$ with running water at $40^{\circ} \mathrm{C}$ for 5 minutes \\
Pre-treat & $:$ with $200 \%$ water at $40^{\circ} \mathrm{C}$ and $2 \%$ leveling agent*8 for 30 minutes at \\
& pH 4.6 \\
Wash & $:$ with running water for 5 minutes \\
Fatliquor & $:$ with $200 \%$ water at $40^{\circ} \mathrm{C}, 5 \%$ fatliquoring agent*4 diluted with $30 \%$ \\
& water at $40^{\circ} \mathrm{C}$ for 30 minutes
\end{tabular}

*1 Relugan GT-50 from BASF Corp. *2 Chromitan MS from BASF Corp, of high basicity * Neutrigan from BASF Corp. *4 Mixture of 2 parts Eukesol fatliquor 1 (sulfited fish oil), 2 parts Eukesol fatliquor SAF (anionic, synthetic oil), and 1 part Eukesol fatliquor A (anionic surfactant)

\section{Processing of chrome leather}

Chrome tanned stocks of different tanning runs were collected together into a lot after storage for a month packed in plastics bags in order to diminish the influence of the variation of time lapse after tanning, and neutralized, retanned, and fatliquored for soft-type chrome leather under the condition as shown in Table 2. They were then hang-dried and toggled.

\section{Physical testing and chemical analysis of leather}

Examinations were carried out by using specimen $20 \times 20 \mathrm{~cm}$ collected from butt portion of dried leather. Tensile and tongue tear strengths and elongation at break were measured according to ALCA method.

\section{Results and Discussion}

The general composition of spent chrome liquors recycled is shown in Table 3 and

Table 3. General composition of spent chrome liquor in recycling

\begin{tabular}{|c|c|c|c|c|c|c|c|c|}
\hline \multirow{2}{*}{$\begin{array}{l}\text { Run No. } \\
\text { of } \\
\text { tanning }\end{array}$} & \multirow{2}{*}{$\begin{array}{l}\text { Weight } \\
\text { of added } \\
\text { chrome } \\
\text { agent g }\end{array}$} & \multicolumn{7}{|c|}{ Composition of spent liquor } \\
\hline & & $\begin{array}{c}\text { chrome } \\
\mathrm{Cr}_{2} \mathrm{O}_{8} \mathrm{~g} / 1\end{array}$ & $\begin{array}{c}\text { basicity } \\
\%\end{array}$ & $\mathrm{pH}$ & $\begin{array}{l}\text { COD } \\
\% *\end{array}$ & $\begin{array}{l}\mathrm{Na}^{+} \\
\%\end{array}$ & $\begin{array}{l}\mathrm{Cl}^{-} \\
\% *\end{array}$ & $\begin{array}{c}\mathrm{SO}_{4}^{-} \\
\% *\end{array}$ \\
\hline 1 & 1200 & 14.3 & 43 & 3. 0 & $\begin{array}{c}100 \\
(688 \mathrm{ppm})\end{array}$ & $\begin{array}{c}100 \\
(0.91 \\
\mathrm{mol} / 1)\end{array}$ & $\begin{array}{l}100 \\
(0.68 \\
\mathrm{mol} / 1)\end{array}$ & $\begin{array}{c}100 \\
(0.27 \\
\mathrm{mol} / 1)\end{array}$ \\
\hline 2 & 512 & 10.7 & 46 & 3. 1 & 117. & 80 & 91 & 98 \\
\hline 3 & 687 & 8.4 & 44 & 3.1 & 123 & 79 & 85 & 99 \\
\hline 4 & 797 & 10.7 & 47 & 3.2 & 149 & 87 & 87 & 114 \\
\hline 5 & 688 & 9.8 & 47 & 3. 1 & $175^{\prime}$ & 85 & 85 & 112 \\
\hline 8 & 701 & 10.7 & 43 & 3. 1 & 172 & 86 & 85 & 115 \\
\hline 11 & 672 & 10.8 & 46 & 3.0 & 151 & 90 & 90 & 112 \\
\hline
\end{tabular}

$15 \mathrm{~kg}$ pelts and 13.51 tanning liquor were used for each run. * based on the content of run No. 1 spent liquor 
Chrome Liquor Recycling in Pigskin Tanning

Table 4. Compositions of chrome complex in recycled spent liquors

\begin{tabular}{rcccccc}
$\begin{array}{c}\text { Run No. } \\
\text { of } \\
\text { tanning }\end{array}$ & $\begin{array}{c}\text { Basicity } \\
(\%)\end{array}$ & $\begin{array}{c}\text { Fractionation of chrome complexes on cation } \\
\text { exchanging column }\end{array}$ fraction 1 & fraction 2 & fraction 3 & $\begin{array}{c}\text { Sulfato graction } 4 \\
\text { fhrome complexes } \\
\text { (\% equivalent to } \\
\text { chrome) }\end{array}$ \\
\hline $\begin{array}{c}\text { Original } \\
\text { liquor }\end{array}$ & 33 & 60 & 9 & 28 & 3 & \\
$\begin{array}{c}\text { Original } \\
\text { liquor }\end{array}$ & 48 & 21 & 5 & 62 & 12 & \\
$\begin{array}{c}\text { Spent liquor } \\
\text { run No. 1 }\end{array}$ & 43 & 16 & 8 & 68 & 9 & \\
2 & 46 & 14 & 8 & 70 & 9 & 21 \\
3 & 44 & 16 & 8 & 64 & 11 & 13 \\
4 & 47 & 19 & 9 & 64 & 9 & 11 \\
5 & 47 & 17 & 6 & 64 & 13 & 16 \\
8 & 43 & 17 & 8 & 69 & 7 & 21 \\
11 & 46 & 17 & 8 & 66 & 9 & 24 \\
\hline
\end{tabular}

the fractional proportion of chrome complexes on cation exchanging column is shown in Table 4.

Except for the increase of $\mathrm{COD}$ in early runs of tanning, the content of general components such as chrome, sodium, chloride, and sulfate ions demonstrates no significant variation by recycling spent chrome liquor.

Compositions of chrome complex in recycled spent liquors also indicate only small variations during sequential 11 runs of tanning and are in such a good similarity to that of the original chrome liquor of basicity $48 \%$ as observed between the original and recycled chrome liquors in cattle-hide tanning experiment ${ }^{14}$. This means that the over-all sorption of chrome complexes by pelt is less selective. This is due to the rapid establishment of the equilibrium in spite of selective sorption of individual

Table 5. Chemical composition of pigskin leathers produced from recycled chrome liquors

\begin{tabular}{ccccccc}
\hline \hline Run No. & $\begin{array}{c}\text { Moisture } \\
\%\end{array}$ & $\begin{array}{c}\text { Hide substance* } \\
\%\end{array}$ & $\begin{array}{c}\text { Fat* } \\
\%\end{array}$ & $\begin{array}{c}\text { Ash* } \\
\%\end{array}$ & $\begin{array}{c}\mathrm{Chrome}_{2}^{*} \\
\mathrm{Cr}_{2} \mathrm{O}_{3} \%\end{array}$ & $\mathrm{pH}$ \\
\hline 1 & 15.8 & 80.1 & 3.3 & 5.9 & 5.0 & 3.3 \\
2 & 14.0 & 80.8 & 3.5 & 5.8 & 5.0 & 3.3 \\
3 & 15.7 & 75.5 & 6.0 & 5.9 & 5.0 & 3.2 \\
4 & 15.9 & 78.4 & 4.5 & 6.0 & 5.3 & 3.3 \\
5 & 16.6 & 79.2 & 4.0 & 5.8 & 4.8 & 3.3 \\
6 & 16.0 & 79.6 & 3.8 & 5.9 & 5.2 & 3.3 \\
7 & 15.0 & 80.1 & 4.2 & 5.8 & 4.9 & 3.3 \\
8 & 14.5 & 79.2 & 4.3 & 5.9 & 5.0 & 3.4 \\
9 & 14.8 & 78.1 & 4.4 & 5.8 & 5.0 & 3.3 \\
10 & 17.0 & 82.8 & 3.6 & 5.6 & 4.9 & 3.3 \\
11 & 16.0 & 80.4 & 3.5 & 5.7 & 4.8 & 3.3 \\
\hline
\end{tabular}

* on the dry weight basis 
chrome compounds. Such nature of chrome sorption is probably one of factors in favor of stabilizing the composition of chrome complexes in spent liquor during recycling.

Chemical compositions of pigskin chrome leathers obtained from recycled chrome liquors are shown in Table 5.

Except for fat content, chemical composition of leather indicates only small variations with recycling and no significant influence of the recycling. Although fat content for run No. 3 is abnormally high, this is probably considered as a contribution not by recycling chrome liquor but by the abnormally small thickness of shaved leather $(0.75$ $\mathrm{mm}$ for run No. 3 against $0.8-0.9 \mathrm{~mm}$ for other runs). The possible explanation is that the thinner shaved leather receives the stronger strain by the same mechanical motion in the drum and so records an enhanced sorption of fat from fatliquoring bath ${ }^{18}$. Therefore, no influence by recycling chrome liquor is observed from the general view of chemical composition of resultant leather.

Tensile and tear strengths, elongation at break, and stiffness by Gurley method are shown in Table 6.

Table 6. Mechanical properties of pigskin leathers produced from recycled chrome liquors

\begin{tabular}{|c|c|c|c|c|c|c|c|c|c|c|}
\hline \multirow[b]{2}{*}{ Run No. } & \multicolumn{4}{|c|}{ Strength } & \multicolumn{2}{|c|}{$\begin{array}{c}\text { Elongation } \\
\text { at break }(\%)\end{array}$} & \multicolumn{4}{|c|}{ Stiffness by Gurley $(10 \mathrm{mg})$} \\
\hline & $\begin{array}{c}\text { tensile } \\
\overline{\mathrm{X}}\end{array}$ & $\begin{array}{c}\left(\mathrm{kg} / \mathrm{mm}^{2}\right) \\
\mathrm{SD}\end{array}$ & $\underset{\overline{\mathrm{X}}}{\text { tongue tear }}$ & $\begin{array}{l}(\mathrm{kg} / \mathrm{mm}) \\
\mathrm{SD}\end{array}$ & $\begin{array}{l}\text { at br } \\
\overline{\mathrm{X}}\end{array}$ & $\begin{array}{l}\text { K }(\%) \\
\text { S D }\end{array}$ & $\underset{\overline{\mathrm{X}}}{\operatorname{grain}}$ & $\begin{array}{c}\text { side-in } \\
\text { SD }\end{array}$ & $\underset{\overline{\mathrm{X}}}{\operatorname{grain}}$ & $\begin{array}{c}\text { side-out } \\
\text { SD }\end{array}$ \\
\hline 1 & 1.5 & 0.2 & 1.5 & 0.4 & 49 & 7 & 274 & 73 & 203 & 19 \\
\hline 2 & 1.5 & 0.4 & 1.5 . & 0.4 & 47 & 7 & 246 & 56 & 203 & 13 \\
\hline 4 & 1.5 & 0.3 & 1.6 & 0.5 & 50 & 8 & 258 & 67 & $20 ?$ & 26 \\
\hline 5 & 1.4 & 0.4 & 1.4 & 0.3 & $41^{* *}$ & 8 & 250 & 59 & 200 & 24 \\
\hline 6 & 1.5 & 0.2 & 1.3 & 0.3 & 48 & 9 & 284 & 63 & 216 & 38 \\
\hline 7 & 1.4 & 0.3 & 1.4 & 0.3 & 46 & 5 & 270 & 68 & 203 & 14 \\
\hline 8 & 1.4 & 0.3 & 1.4 & 0.3 & 47 & 9 & 264 & 76 & 208 & 24 \\
\hline 9 & 1.4 & 0.3 & 1.4 & 0.4 & 47 & 8 & 272 & 72 & 210 & 18 \\
\hline 10 & 1. 4 & 0.3 & 1.7 & 0.5 & 48 & 8 & 262 & 67 & 219 & 39 \\
\hline 11 & 1.6 & 0.2 & 1.8 & 0.6 & 52 & 9 & $320^{* *}$ & 76 & $245^{* *}$ & 59 \\
\hline
\end{tabular}

** The difference against the run No. 1 value is significant by $1 \%$ level.

Data for run No. 3 have been omitted from the table because this lot of leather has the defects of abnormal thickness and fat content described above. The difference of average value of tensile and tear strengths and elongation between run No. 1 and a run of No. 4 to No. 11 was statstically insignificant. For stiffness, which may be considered as a more sensitive parameter concerning physical condition of leather ${ }^{19}$, the difference from run No. 1 was also insignificant except for run No. 11. Although the reason of slightly higher stiffness of run No. 11 leather can not be exactly explained, variations of operational conditions among these lots may be involved.

As a conclusion, the recycling of chrome liquor in pigskin tanning does not affect the properties of pigskin leather and can also be recommended to put in practice. 


\section{References}

1) Kuro, T. and K. Shirai, Jpn. J. Zootech. Sci., 51: 100-104. 1980.

2) Kuso, T. and K. Shira1, Jpn. J. Zootech. Sci., 51: 279-283. 1980.

3) Kubo, T., K. Shirai and K. Wada, HiKAKU-KAGAKU, 25: 237-240. 1980.

4) Нauck, R. A., J. Am. Leather Chem. Ass., 67: 422-429. 1972.

5) Davis, M. H. and J.G. Scroggre, J. Soc. Leather Tech. Chem., 57: 53-58. 1973.

6) Davis, M.H. and J.G. Scroggie, J. Soc. Leather Tech. Chem., 57: 81-83. 1973.

7) Davis, M. H. and J.G. Scroggie, J. Soc. Leather Tech. Chem., 57: 173-176. 1973.

8) Davis, M.H. and J.G. Scroggie, Das Leder, 31: 1-8. 1980.

9) Burns, J. E., D. E. Colquitt, M. H. Davis and J. G. Scroggie, J. Soc. Leather Tech. Chem., 60: 106-112. 1976.

10) France, H. G., J. Am. Leather Chem. Ass., 70: 206-216. 1975.

11) Pierce, R. and T. C. Thorstensen, J. Am. Leather Chem. Ass., 71: 161-168. 1976.

12) Barlow, J.R. and H.S.W. IP, J. Soc. Leather Tech. Chem., 61: 29-33. 1977.

13) Niwa, Y., M. Kawakami and I. Yokokawa, HIKAKU-KAGAKU, 21: 232-243. 1975.

14) WADA, K., K. Shiral and T. Kubo, J. Am. Leather Chem. Ass., under supervision for J. Am. Leather Chem. Ass.

15) Wada, K., K. Shiral and A. Kawamura, J. Am. Leather Chem. Ass., 75: 90-99. 1980.

16) Standard Method for Examination of Water and Waste-Water. 13th ed. 1971. American Public Health Assoc.

17) Kawamura, A. and K. Wada, J. Am. Leather Chem. Ass., 52: 476-488. 1957.

18) Shirai, K., T. Chang and H. Okamura, HiKaKU-KaGaKU, 18: 13-27. 1972.

19) Shirai, K. and H. Okamura, HiakKU-KaGAKU, 18: 203-215. 1973.

\section{豚皮のなめしにおけるクロム液の循環利用}

\section{久保知義・石井泰博}

\section{東京農工大学㟽学部硬蛋白質利用研究施設, 府中市 183}

溌皮のなめし工程におけるクロム液の循環再利用を牛 革の製造に乱ける技術的な経験を適用して研究した。す なわち，豚皮の亜硫酸還元クロムなるしに抢いてクロム 夜を 11 回循環再利用してンフトタイプクロム革を製造 し，循環に伴うクロム排液の組成と製出革の性状を調べ

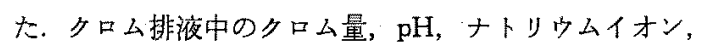
塩素イオン及び硫酸イオン，並びにクロム錯イオンの電
荷分布などの成分組成は 11 回の偱環再利用による翂動 をほとえど示さなかった。また，クロム排液の循㻴利用 に上る製出革の化学組成，並びに機械的強度と剛軟度一 の影響は少なかった。以上の結果から，豚皮を対象とし たクロムなめしにおける排液の循環利用は，牛皮と同様 に実用化が可能である。

日畜会報, $52(4) ： 308-313,1981$ 